\title{
Un cine fuera de sí: terrorismo estilístico en el udigrudi brasileño
}

\section{A Cinema Outside of Itself: Stylistic Terrorism in Brazilian udigrudi}

\begin{abstract}
Resumen
A fines de la década del sesenta surge en Latinoamérica un movimiento de cine underground que busca, a través de la experimentación formal radicalizada, construir un discurso político. Estas películas confrontan, a la vez, con el cine de autor y con el cine militante. Más allá de una compartida actitud contracultural, en cada país el movimiento underground adquiere rasgos diferentes. Este artículo analiza los modos implementados por el udigrudi brasileño para conspirar contra el cinéma d'auteur y construir un autor de identidad mutante: el autor cinematográfico ya no es una subjetividad que se expresa artísticamente ni el portavoz político de los oprimidos, más bien actúa como un francotirador que nunca está allí donde se lo busca.
\end{abstract}

Palabras claves Cine underground, udigrudi brasileño, cinema novo, cine militante, Rogério Sganzerla, Júlio

Bressane

\begin{abstract}
The movement of underground cinema emerges in Latin America in the late sixties and, through radical formal experimentation, it tries to shape a political discourse. These films confront both with author cinema and with militant cinema. Apart from a shared countercultural attitude, the underground movement adopts different traits in each country. This article studies the modes implemented by Brazilian udigrudi to attack the cinema d'auteur in order to produce the figure of an author with mutant identity: cinematographic author is not anymore a subjectivity expressing itself artistically nor the political spokeperson of the opressed people but, instead, a sniper constantly in movement.
\end{abstract}


CATEDRAL Tomada: Revista de crítica literaria latinoamericana / Journal of Latin American Literary Criticism Un cine fuera de sí: terrorismo estilístico en el udigrudi brasileño

Keywords Underground cinema, Brazilian udigrudi, cinema novo, militant cinema, Rogério Sganzerla, Júlio Bressane

\section{Introducción}

El modelo de los nuevos cines a comienzos de los años sesenta había sido el cine de autor europeo; pero para el momento en que surgen los "nuevos cines nuevos" en Brasil y Argentina a finales de esa década, habría que considerar, también, la entrada en escena del underground norteamericano. Digamos: del cine de arte a la contracultura. En 1954, André Bazin había sido invitado al Festival de cine de San Pablo; en 1962, en cambio, el invitado extranjero en el Festival de Mar del Plata es Jonas Mekas, que exhibe allí su película Guns of the trees (1961). ${ }^{1}$ Poco después, en 1965, el crítico y poeta Miguel Grinberg organiza en el Instituto Di Tella un ciclo sobre el New American Cinema donde se muestran films de Adolfas y Jonas Mekas, Stan Brakhage, Shirley Clarke, Ken Jacobs, Kenneth Anger, Bruce Conner, Lionel Rogosin y Andy Warhol, entre otros.

Escribe Grinberg en el catálogo para la muestra en el Di Tella:

Estamos en la antesala del cine poético: rechazo del cine 'profesional' y entrada al cine 'amateur' ('amador', del latín amare), donde el film es la creación integral de un hombre o una mujer, sin productores industriales y sin condicionamiento a la explotación comercial del producto, como si se tratara de un poema o un cuadro. (La generación " $V$ " 145)

${ }^{1}$ Véase la reseña del festival que Bazin publica en Cahiers du cinéma al regreso de San Pablo: "Un festival de la culture cinématographique". El crítico también escribe "De la dificulté d'etre Coco", un texto encantador sobre los problemas aduaneros que padeció con un loro que había comprado en Brasil y que se publicará en el número especial de Cahiers luego de su muerte. Sobre la influencia de Bazin en la crítica brasileña, véase Ismail Xavier, "Bazin in Brazil: A Welcome Visitor". 
Significativamente, el texto avanza en la misma dirección que un ensayo posterior de Brakhage donde también se rescata la figura del cineasta como amateur (frente a otras definiciones como "profesional" o "artista"). ${ }^{2}$ Es indudable que el contacto con el cine experimental norteamericano deja sus marcas; pero aunque los directores argentinos y brasileños comparten con esos films una misma actitud contracultural, no se proponen como amateurs porque nunca renuncian a los formatos tradicionales ni a la exhibición comercial de sus películas (aun cuando, en la mayoría de los casos, fueron censuradas o tuvieron una circulación muy restringida). ${ }^{3}$ Brakhage define al amateur como alguien que trabaja en soledad incluso si eventualmente se asocia a otros amateurs- y que no busca el reconocimiento público; pero para el underground latinoamericano, no se trata de dar la espalda al público sino, precisamente, enfrentarse a él.

Este artículo analiza las estrategias de "terrorismo formal" implementadas por los cineastas del movimiento udigrudi en Brasil, a fines de los años sesenta y comienzos de los años setenta. Me interesa indagar, sobre todo, en sus cuestionamientos a la tradicional figura del autor cinematográfico tal como se plantean en estos films desde una perspectiva muy diferente a la del cine militante de ese mismo período.

2 El texto de Stan Brakhage, "In Defense of amateur", fue publicado originalmente en 1971 y luego recogido en Essential Brakhage: Selected Writings on Film-Making.

3 En su artículo "Cinema marginal?", Jean-Claude Bernardet señala que el cine underground brasileño, también llamado cinema marginal, debería llamarse cinema marginalizado porque sus realizadores no pretendían quedar afuera de los circuitos de exhibición sino que, justamente, fueron los exhibidores y la censura quienes marginaron sus films. En la Argentina, Ludueña señala que, a partir de The Players vs. Ángeles caidos (Alberto Fischerman, 1969), los cineastas independientes se ilusionaron con la posibilidad de filmar libremente en $35 \mathrm{~mm}$ y estrenar en una "sala chiquita"; sin embargo, la mayoría de las películas del underground no lograron estrenarse en su momento (Sarlo 146-147). 


\section{La subversión del mal gusto}

La noción de cine de autor tuvo sus primeras formulaciones en los textos de los jóvenes críticos de Cahiers du cinéma que, durante los años 50, salieron en defensa de una politique des auteurs. Tal como afirma François Truffaut: "Basada en su totalidad en la bella fórmula de Giraudoux, 'No hay obras, sólo hay autores', esta política consiste en negar el axioma, tan querido por nuestros predecesores, según el cual con las películas ocurre lo mismo que con la mayonesa: o se fracasa en el intento o se logra hacerla bien” (“Alí Babá et la politique des auteurs" 47). Los postulados de esa política de los autores se oponían a dos de los prejuicios críticos más difundidos en la posguerra: por un lado, un autor es autor más allá de films mayores o menores y, por otro lado, su obra presenta una determinada visión del mundo desplegada a través de un universo estilístico personal. ${ }^{4}$ De este modo, las nociones de autor y de puesta en escena se implican mutuamente: un autor se define por su particular modo de concebir la puesta en escena y la coherencia de la puesta en escena revela la impronta de un autor. Desde entonces, el cine de autor ha estado asociado a la idea de un cine de expresión personal y con aspiraciones artísticas.

El cine militante, en cambio, se ubica en el polo opuesto. No piensa en las películas como medio de expresión individual sino como vehículos del activismo y de la contrainformación que deberían contribuir a concientizar sobre la necesidad de un cambio radical. El final de la década de 1960 y comienzos de la siguiente señala el auge del cine militante en Latinoamérica: un cine que no sólo comunica un discurso político sino que promueve una acción transformadora fuertemente politizada. Tal como escriben Fernando Solanas y Octavio Getino:

${ }^{4}$ Sobre el concepto de autor cinematográfico, puede consultarse John Caughie, Theories of Authorship. Y sobre la noción de autor en Cahiers du cinéma, véase la recopilación de textos de la revista: Antoine de Baecque (ed). La política de los autores. Manifiestos de una generación de cinéfilos. 
Lo que define a un film como militante y revolucionario son no solamente la ideología ni los propósitos de su productor o su realizador, ni aún siquiera la correspondencia existente entre las ideas que se expresan en el film y una teoría revolucionaria válida en determinados contextos, sino la propia práctica del film con su destinatario concreto: aquello que el film desencadena como cosa recuperable en determinado ámbito histórico para el proceso de liberación. $(132-133)^{5}$

Por eso, en diálogo con Jean-Luc Godard, Solanas afirma que la verdad es subversiva y que aquellos que pretenden ser autores dentro del sistema no hacen más que continuar con "un juego imposible" porque allí los cineastas están condenados a "autoreprimirse (sic), autocensurarse, autocastrarse creativamente" (55). A su turno, Godard completa la idea relegando al pasado toda posibilidad de contestación en el cine de autor: "La noción de 'autor' era una revolución en los tiempos en que el autor luchaba contra el productor, un poco a la manera en que en la edad media luchaba un burgués contra un señor. Ahora el burgués se ha convertido en un señor, el autor ha reemplazado al productor. Por lo tanto no hace más falta un cine de autor, porque cuanto más es un cine a nivel de la revolución burguesa" (57-58). ${ }^{6}$ Esa fantasía sobre un borramiento del autor -acaso irrealizable - tensiona los vínculos entre estilo individual y proyecto político colectivo en muchos de los grupos de cine militante en Latinoamérica: Cine Liberación, Ukamau, Cine de la Base. Frente a esta disyuntiva entre la revolución y lo individual, el cine underground plantea un tercer punto de vista donde la figura del autor y la pulsión de la política se reformulan de maneras muy singulares.

5 Para una caracterización del cine militante como acción política, véanse Mariano Mestman, "Aproximaciones a una experiencia de cine militante (Argentina, 1968-1973)" y Emilio Bernini, "La vía política del cine argentino. Los documentales". Sobre los diferentes modos de entender el cine politico, véase Mateus Araújo Silva, "Godard, Glauber e o Vento do leste: alegoria de um (des)encontro".

6 Sobre el cine político y su crítica a la noción de autor, véanse David Rodowick, The Crisis of Political Modernism y David Faroult, "Never more Godard. Le Groupe Dziga Vertov, l'auteur et la signature". 
El underground argentino y el udigrudi brasileño comparten una misma franja temporal (surgen como reacción frente al aparato represivo de las dictaduras militares) y un mismo arsenal de estrategias radicalizadas dirigidas contra el establishment; pero también expresan un violento desencanto frente a la emergencia de un cine militante que sacrifica todo a la comunicación de un mensaje (el under porteño contra el cine militante) o frente a un movimiento de ruptura que ya no es considerado lo suficientemente audaz como para desmontar las convenciones del cine más comercial (el udigrudi contra el cinema novo). Producto del "Ato Institucional Número 5" de 1968 -el llamado "golpe dentro del golpe"que profundizó el autoritarismo del dictador Arthur da Costa e Silva, el udigrudi o cinema marginal pretende ir más allá de la ruptura de los cinemanovistas y reclama una radicalización de sus postulados iniciales. Para Avellar, se trata de entender la marginalidad de las nuevas películas "como uma atitude do realizador, como resultado de um desejo consciente de permanecer à margem. A condição de marginal não é uma coisa exterior ao filme. Não é um estigma imposto ao filme. É um sentimento intrínseco ao projeto. A marginalidade, aquí, não é uma questão económica. É uma questão política" (O cinema dilacerado 89 ). ${ }^{7}$

En efecto, los esfuerzos del cinema novo por intervenir en el debate político habían llevado a sus directores a realizar películas que interpelaran más abiertamente al público y que, por lo tanto, alcanzaran una mejor distribución y una mayor conciliación con el mercado (sobre todo, a través de la empresa estatal Embrafilme). Como sostiene Ismail Xavier:

A eficiência no mercado, como um valor, fora questionada no início dos anos 60 , quando a ideia do cinema de autor ganhara uma formulação antiindustrial e uma proposta de cinema político tornara opostos arte e comércio. No final da década, a mesma efíciência foi um dos elementos

${ }^{7}$ Sobre el underground argentino y el udigrudi brasileño, véanse Paula Wolkowicz, "El héroe ausente. La figura del líder, del pueblo y del intelectual en el cine marginal brasileño y en el cine underground argentino" y Daniel Pecego Vieira Caetano, Entre a transgressão vanguardista e a subversão da vulgaridade: Os casos de Carlos Reichenbach e Alberto Fischerman. 
divisores na polêmica que envolveu cineastas do cinema novo e uma nova geração que exigia a continuidade de uma estética da violência, de um cinema mais empenhado na expressão radical do autor do que nas concessões viabilizadoras dos filmes como mercadoria. (Alegorias do subdesenvolvimento 30 )

Así, continuando el camino abierto por $A$ margem (Ozualdo Candeias, 1967) y O bandido da luz vermelha (Rogério Sganzerla, 1968), las películas del udigrudi se amontonan en una rápida sucesión: Matou a familia e foi ao cinema (1969) у O anjo nasceu (1969) de Júlio Bressane; A mulher de todos (1969) y Sem essa, aranha (1970) de Sganzerla; Blá blá blá (1968) y Bang Bang (1971) de Andrea Tonacci; Jardim de guerra (Neville Duarte d'Almeida, 1970); Orgia, ou o homem que deu cria (Joao Trevisan, 1970).

Estos nuevos films son irreverentes, violentos, desesperados, intrépidos, sucios. Se agrupan bajo la denominación de udigrudi, cinema marginal, cinema cafajeste o cinema da Boca do Lixo (por el barrio lumpen de San Pablo donde se concentraban estas pequeñas productoras), entre otras denominaciones más o menos provisorias. A propósito de la exhibición de $A$ mulher de todos, Sganzerla escribe una nota donde ataca al cinema novo por "falsificar nossa realidade com academicismos mediocres e orçamentos astronómicos" y desprecia a los críticos que no entienden su película porque es más inteligente que ellos:

Dentro do lixo, é preciso ser radical. Daí o amor pelo cinema brasileiro tal como ele é: mal feito, pretensioso e sem pretensões e ilusões estéticas. Esmagado e explorado, o colonizado só pode inventar seu próprio sufocamento: o grito do protesto vem da mise en scène abortada. Ninguém pensa de forma limpa e estética de barriga vazia. Continuo realizando um cinema subdesenvolvido por condição e vocação, bárbaro e nosso, anticulturalista, buscando aquilo que o povo brasileiro espera de nós desde 
o tempo da chanchada: fazer do cinema brasileiro o pior cinema do mundo! Ah, como isso seria maravilhoso e sensato! ("A mulher de todos") ${ }^{8}$

Por eso, entonces, el pasaje de una estética da fome (tal como la planteaban Glauber Rocha y el cinema novo) a una estética do lixo: si aquella era la expresión utópica de una falta (y, por lo tanto, estaba guiada por una teleología), ésta señala con desencanto hacia el excedente, lo que sobra, lo que se deshecha (la basura que produce el consumo). Por eso, también, el pasaje de una violencia revolucionaria (organizada) a una violencia catártica (desesperanzada). Si el cinema novo buscaba una comunidad entre director y espectadores, los films del udigrúdi ejercen una agresión anárquica contra el público. No apelan a su comprensión (y mucho menos a la concientización).

Experimentales, extravagantes, exasperadas, estas películas descubren una forma crispada de belleza en las imágenes de criminales incurables vagabundeando por las calles de la ciudad que es mostrada como un paisaje después del cataclismo. Entrevistado por célebre semanario O Pasquim, Sganzerla afirma que Antonio das Mortes (Glauber Rocha, 1969), Brasil ano 2000 (Walter Lima Jr., 1969) y Macunaíma (Joaquim Pedro de Andrade, 1969) son los peores films brasileños, acusa a Rocha de decadente y concluye que el cinema novo se ha convertido en un movimiento anticuado, paternalista y de derecha. ${ }^{9}$ En una modulación muy Grupo Dziga Vertov, Neville Duarte d'Almeida critica al cinema novo por "its

${ }^{8}$ En diversas ocasiones, Reichenbach y Sganzerla declaran su afición por lo vulgar, lo panfletario, lo bajo. Con orgulloso desprecio, se refieren a sus películas como filmecos. Y en el manifiesto "Nasce o cinema cafajeste", João Callegaro escribe: "Cinema cafajeste é cinema de comunicação direta. É o cinema que aproveita a tradição de 50 anos de exibição do 'mau' cinema americano, devidamente absorvido pelo espectador e que não se perde em pesquisas estetizantes, elocubrações intelectuais, típicas de uma classe média semi-analfabeta" (citado en Ferreira, Cinema de invenção 101).

${ }^{9}$ Véase Sganzerla e Ignez, "Helena -a mulher de todos- e seu homem". En una carta a Alfredo Guevara, Glauber Rocha se queja porque entiende que la entrevista es una venganza contra la independencia del cinema novo. Sganzerla ha dicho que no piensa protestar contra el encarcelamiento de Joaquim Pedro de Andrade porque, además de comunista, le parece un pésimo cineasta. Rocha escribe: "Num país fascista como o Brasil, estas frases de efeito fazem suceso para uma imprensa irresponsável" (Cartas ao mundo 407). 
humillating, subservient and culturally underdeveloped condition of subproduct of the Hollywood-Cinecitta-Rive Gauche circus" (citada en Stam 38).

\section{El cinema novísimo contra el cinema novo}

En una entrevista con Cahiers du cinéma a fines de 1970, el realizador Carlos Diegues afirma que, para preservar los logros del cinema novo, es necesario darlo por terminado antes de caer en el academicismo: "Desde el comienzo hemos hecho un cine muy 'social' y luego hemos llegado a un cine político por la vía del autor. El cinema novo siempre ha sido más personal cuando ha sido más político y viceversa" ("Entretien avec Carlos Diegues" 47). Es cierto que la industria que se ha creado en Brasil no es la que el cinema novo había soñado de una manera demasiado idealista (una "industria de autores”), pero según Diegues las propuestas del cinema marginal resultan nihilistas y peligrosas:

Se corre el riesgo de pasar de un sentimiento de impotencia al cinismo, del cinismo al absurdo, del absurdo al compromiso con la muerte, es decir al suicidio cultural y político que está muy a la moda entre algunos sectores de la juventud mundial [...] Ellos [lo cineastas del udigrudi] quieren hacer en Brasil un cine 'underground', hippie, un cine del absurdo, de la angustia existencial, un cine irresponsable y peligroso en el caso de Brasil porque, al fin y al cabo, resulta escapista aunque quiera parecer revolucionario. $(48-49)$

Diegues hace un esfuerzo por inscribir el cinema novo dentro de la gran historia del cine mientras que el cinema marginal quedaría reducido a una disputa mezquinamente parroquial. Porque los cinemanovistas comenzaron a hacer films gracias al cine clásico y la Nouvelle vague; los del udigrudi, en cambio, conocieron a Rocha antes que a Eisenstein y a Pereira dos Santos antes que a Renoir. Es un 
movimiento cortoplacista que no está animado por una renovación profunda sino que sólo pretende arrebatar una posición que ya está ocupada. En efecto: si el cinema marginal confronta con el cinema novo es porque surge de ahí (de hecho, en un primer momento, algunos críticos usaron los términos cinema novísimo o novo cinema novo para señalar esa genealogía). Profundización y reacción, a la vez, estas películas bizarras exacerban de manera paródica la desmesura propia del estilo de Glauber.

Rocha responde con furia y denuncia que eso que parece revulsivo ya lo había descubierto, años antes, el cinema novo: "Jovens cineastas, como Tonacci, Sganzerla, Bressane, Neville e outros de menor talento, que se levantaram contra o Cinema Novo anunciando uma velha novidade: cinema barato de câmara na mão e idéia na cabeça" ("Udigrudi: uma velha novidade" 80 ). ${ }^{10}$ Pero también es cierto que, en sus películas de la década del 70, el más radical de los cinemanovistas acabará dialogando (un diálogo, por supuesto, tenso y polémico) con los cineastas marginales, disputándoles esa colocación extrema y rupturista a la que aspira toda vanguardia. Parece evidente que Glauber no tolera esa competencia. Permanentemente se queja por las traiciones de Sganzerla y de Julinho (Bressane), como si no quisieran admitir que son hijos del cinema novo. En una carta a Diegues, adopta un tono paternal y falsamente comprensivo con los jóvenes tropicalistas: afirma allí que no tiene sentido ser implacables con ellos tal como ellos lo han sido con el cinema novo y que tampoco hay que:

cobrar pros meninos o sucesso dos filmes, que afinal chegaram atrasados à festa dos anos sesenta, segurando o caixão do defunto da constestação festiva, quando o cinema novo, unico verdadeiro movimiento revolucionário cultural do terceiro mundo et ailleurs (revolucionário, digo,

\footnotetext{
${ }^{10}$ Como se ve, a Glauber le molesta lo que considera una expropiación del lema que él mismo había propuesto para definir al cinema novo. Pero incluso cuando Reichenbach defiende a Sganzerla, se pregunta: "seria ele um Glauber do asfalto?" (citado en Vieira Caetano 31). Más allá de los celos, las traiciones y la competencia, luego habrá reconciliación: cuando Rocha muere, Sganzerla escribe una admirativa necrológica (véase "Necrológio de um gênio").
} 
na sua praxis e linguagem económica / estética saídas do terceiro mundo), entrou em recesso porque não quis dobrar a espinha, ou seja, sair pelo revisionismo de direita da pop art. (Cartas ao mundo 413-414)

El udigrudi coincide con el momento cultural del Tropicalismo y, de hecho, el Glauber que discute con los cineastas marginales es un Glauber tropicalista y caníbal post 68. Mientras que en sus inicios, el cinema novo había procurado inscribirse en la tradición de la literatura social de los años treinta, ahora el tropicalismo y los jóvenes realizadores recuperan el modernismo temprano de Oswald de Andrade y de su Manifesto antropófago (1928). Esa elección:

supõe o modelo digestivo pelo qual a identidade do autor e a obra são entendidas como processos, não substâncias. Ou seja, como atividades que envolvem operações de assimilação crítica pelas quais incorporamos qualquer traço de alteridade, imposto (como na situação colonial) ou simplesmente encontrado, fazendo-o uma parte integrante de um projeto que se desdobra em resposta original, pois promove uma re-significação das referências. Não há, portanto, substância nacional (ou pessoal) a preservar, um patrimônio pelo qual se deva zelar contra contaminações (estas são as próprias matérias de que somos feitos). O que há é uma incessante interação que a cultura industrializada do século $\mathrm{XX}$ só veio intensificar. (Xavier, "Roteiro de Júlio Bressane" 7) ${ }^{11}$

Los cineastas del udigrudi plantean ese rescate de Oswald por oposición a la figura de Mario de Andrade; en este sentido, reproducen el esquema clásico de la historiografía crítica que quiso ver, en la pelea entre ambos escritores, el señalamiento de dos líneas opuestas del modernismo: el internacionalismo antropofágico versus el purismo nacionalista. Sganzerla actualiza y explícita ese

\footnotetext{
${ }^{11}$ A propósito de esta cuestión véase, también, Xavier: “O cinema marginal revisitado, ou o avesso dos anos 90”.
} 
enfrentamiento como si se tratara una confrontación entre el trotskismo del udigrudi y el stalinismo latinoamericano del cinema novo ("A questão da cultura"). Contra la moral estalinista, contra el culturalismo, contra el reformismo populista, el cinema marginal se propone como la única solución. El cinema novo había hecho todo lo necesario para diferenciarse de la falsa calidad industrial de los estudios Vera Cruz y había logrado construir un hondo compromiso con la realidad sociopolítica, aunque un gesto adusto y solemne persistía en sus films. Humor había en las chanchadas, pero el cinema novo había rechazado esas películas porque veía en ellas el modelo de una cultura popular degradada; el udigrudi, en cambio, encuentra allí, en ese género despreciado, un prisma a través del cual practicar una lectura corrosiva de la modernidad. ${ }^{12}$

El centro de gravedad (o de ingravidez) de estos nuevos films consiste en una representación violenta e irreverente de la cultura de masas como un espacio de contaminación donde se entremezclan la prensa amarilla, el Pop Art, los malos shows de TV, la películas de la serie B, las fotonovelas eróticas, los comics, los films de terror de José Mojica Marins, el teatro de revistas, la moda vulgar, el kitsch. El cinema marginal apuesta al pastiche irreverente, a la relectura canibalizada, a la desfiguración profanadora. En el manifiesto "Cinema fora da Lei” (que Sganzerla redacta durante el rodaje de $O$ bandido da luz vermelha), el film se define como:

um far-west sobre o Terceiro Mundo. Isto é, fusão e mixagem de vários generos. Fiz um filme-soma; um far-west, mas também musical, documentário, policial, comédia (ou chanchada?) e ficcão científica. Do documentário a sinceridade (Rossellini); do policial, a violencia (Fuller); da comédia, o ritmo anárquico (Sennett, Keaton); do western, a simplificacão brutal dos conflitos (Mann). (15)

\footnotetext{
${ }^{12}$ Sobre la redención de las chanchadas por parte del udigrudi, véase João Luiz Vieira, "Chanchada e a Estética do lixo".
} 
Si para los jóvenes turcos de Cahiers du cinéma, la politique des auteurs había enseñado a descifrar al cineasta a través (o detrás) del género, ahora el director es un nómade que vive en (o entre) los géneros.

\section{Por un cine fuera de sí}

Sylvain Dreyer señala que "la escena primaria" del cine militante francés es el momento en que Chris Marker proyecta $\grave{A}$ bientôt j'espère (sobre la fábrica Rhodia de Besançon) a los propios obreros y ellos reaccionan violentamente porque sienten que han sido explotados por un film que dice luchar contra la explotación. Marker responde:

Nosotros seremos siempre los exploradores bien intencionados, más o menos simpáticos, pero venidos del exterior [...] La representación y la expresión del cine de la clase obrera será fruto de ella misma. Cuando los trabajadores tengan en sus manos los aparatos audiovisuales, recién ahí nos mostrarán los films sobre la clase obrera. ("Le cinéma militant et le mythe du collectif' 36) ${ }^{13}$

Sin embargo, no es tan evidente que la solución deba pasar por allí en todos los casos. Jean-Pierre Thorn, por ejemplo, se resiste a abandonar la idea de que el cine es ante todo una escritura y por lo tanto adopta el camino inverso: para él no se trata de entregar la cámara a los obreros sino de transformar radicalmente la propia perspectiva para aprender a mirar como uno de ellos. Durante diez años, Thorn abandona el cine para trabajar como operario en una fábrica. Es una opción

13 Sobre el pasaje de la voz del autor a las manifestaciones de los colectivos políticos, véanse las diferentes ponencias planteadas en los coloquios de Rennes 1977, 1978 y 1979 recogidas en Guy Hennebelle, Cinéma et politique. De la politique des auteurs au cinéma d'intervention. Sobre el cine de intervención política en Latinoamérica, véanse Fernando Solanas y Octavio Getino, Cine, cultura y descolonización y Octavio Getino y Susana Velleggia, El cine de las historias de la revolución. 
extrema pero, de alguna manera, intenta encontrar una solución para el problema de un cine que ya no quiere hablar para sus espectadores sino hablar con-e incluso desde- ellos. Buena parte del cine de intervención política que se realiza en Latinoamérica durante los sesenta y los setenta se plantea ese objetivo. Un devenirespectador por parte del autor y un devenir-autor para los espectadores. Las imágenes no deberían desbordar sobre sus interlocutores; más bien, son los interlocutores quienes se sumergen en el film y buscan reconocerse en las imágenes. La película es una interpósita persona. No importa quién habla porque dice lo que cualquier espectador podría decir. Habla como hablaría un delegado gremial: habla por todos. Es sólo un portavoz o un catalizador de los reclamos colectivos. El pluralis auctoris es aquí un modo de indicar que la película disuelve el hiato que la separa del público a quien se convoca para participar en la lucha.

El cinema novo y el cine militante, más allá de sus diferencias, funcionan de manera inclusiva como expresión de los deseos colectivos. Mediante la persuasión o el debate, las películas buscan una identificación con el público; cineastas y espectadores pertenecen a una misma comunidad de intereses compartidos. Es lo que dice Carlos Diegues: hay que hacer un cine nacional que sea popular y de autor a la vez. El cine underground, en cambio, ataca al público, lo injuria, se pelea con él. No pretende colocarlo de su lado sino, más bien, escandalizarlo y violentarlo. Contra el "cinema bem feito", la estética do lixo se presenta como la representación más acabada de ese Tercer mundo adonde van a parar todos los detritus del capitalismo. Acusados de regodearse en la basura, los cineastas marginales responden que es necesario alienarse para mostrar la alienación. El cineasta es como el tábano de Sócrates o, incluso mejor, el pez torpedo. Cuando Menon le dice a Sócrates que sus fascinantes argumentaciones lo han hechizado, así como el pez torpedo paraliza a sus presas con una descarga eléctrica, el filósofo responde que sólo acepta la comparación a condición de que ese pez torpedo que adormece a los otros peces esté él mismo adormecido: "Porque si llevo la duda al espíritu de los demás no es porque yo sepa más que ellos, sino todo lo contrario; pues yo dudo más que nadie, y así es como hago dudar a los 
demás". Hay, entonces, un espíritu socrático en esos realizadores; pero se trata, en todo caso, de una mayéutica exasperada y brutalista.

El underground rompe con la noción de cine de autor, no con la idea de autor. Pero será un autor anárquico y visionario que no se define por la opresión de un estilo cohesionado ("ese último respiro liberal -como diría Sganzerla- de la democracia occidental"). El cine no exterioriza una subjetividad sino que permite escapar a ella porque devora todo. Y así como en el "Manifesto antropófago", Oswald de Andrade afirmaba "só me interessa o que näo é meu", en esa misma línea Bressane declara que el cine sirve para descentrarse, para estar fuera de sí. Las películas no deberían (sólo) expresar una subjetividad sino que deberían funcionar como "un poderoso instrumento de autotransformación" (Bressane et al, “O eu da arte é fora de si" 25). ${ }^{14}$ Éste es un cine que no dice "yo", o en todo caso: ya no sabe qué dice cuando dice "yo" porque siempre dice varias cosas a la vez. Los personajes del udigrudi son singularidades opacas e irreductibles, así como los del under porteño son actantes vacíos (porque son estereotipos o alegorías donde se arruinan el estereotipo y la alegoría). Dentro de esa misma cavidad queda definida la figura del autor en estas películas: un sujeto impenetrable o en disponibilidad. Más que por aquello que exterioriza, se define por aquello que recibe, que lo impregna y lo llena. Si hay un autor en $O$ anjo nasceu o en Bang Bang o en A mulher de todos, es un sujeto de identidad mutante porque el estilo de estos films consiste justamente en cuestionar la fijeza del estilo. El enunciador no se define por su cohesión sino, más bien, por las discontinuidades que lo atraviesan. Ya no es un cine de autor sino un cine de deixis: sus enunciados son siempre relativos y requieren de un punto de referencia exterior al discurso para conferirles un sentido.

El autor no es una intimidad que se expresa ni un portavoz de los oprimidos, más bien un francotirador que nunca está allí donde se lo busca. Un tirabombas.

\footnotetext{
${ }^{14}$ Entendido de esa manera, el cine es instrumento de autotransformación, es decir: "trans-formaacción" (Avellar, "El desierto en transe" 18).
} 
Marginal y héroe, como quería Hélio Oiticica. Héroe marginal. O como se pregunta el cartel luminoso al comienzo de $O$ bandido da luz vermelha: "Um genio ou uma besta?" La declaración de Sganzerla sobre un cine fuera de la Ley concluye: “O ponto de partida de nossos filmes debe ser a instabilidade do cinema-como também da nossa sociedade, da nossa estética, dos nossos amores e do nosso sono. Por isso a câmara é indecisa; o som fugidio; os personagens medrosos. Nesse país tudo é possivel e por isso o film pode explodir a qualquer momento ("Cinema fora da Lei" 17). Y lo cierto es que Bressane se refiere a su film Matou a familia e foi ao cinema como "una bomba atómica" estallando en el contexto represivo de finales de la década y agrega:

Estas películas, por la forma que tenían, tomaban partido por la lucha armada, por el terrorismo [...] Lo que nosotros hicimos fue una traducción, en términos formales, de la guerrilla al cine. Hacer una película en pocos días, con poco material, poca gente enterada, con mucha precisión para hacer todo rápido... Y la violencia del lenguaje, más fuerte que una ametralladora. Todo eso está en las películas. Están impregnadas de la época, la violencia, la belleza sensual de entonces, la gracia. ("La patología engendra el estilo" 34-35)

Montaje nervioso, banda sonora estridente, cámara histérica, musicalización hiperquinética, gestualidad desaforada: en el film de Sganzerla se señala que "los personajes no pertencen al mundo sino al tercer mundo" y luego se anuncia que "el tercer mundo va a estallar". Cine apocalíptico para denunciar la destrucción. 


\section{Conclusión}

Así como hay un tono inevitablemente sacrificial en el discurso del cine militante, no deja de haber algo ingenuo en este terrorismo de la imaginación que es tan propio del udigrudi brasileño como de los "happenings pesimistas" del underground porteño, siempre asociados a la rebelión del mayo francés. Es cierto que, de todos modos -incluso en su formalismo vehemente-, las películas del udigrudi brasileño son más radicalmente políticas que las de la vanguardia argentina. Se trata de un movimiento más desencantado, más oscuro, más inadaptado, más resentido, donde la violencia y la agresión aparecen como componentes estructurales. Menos psicodélico y más beatnik. Digamos: no es lo mismo Warhol (siempre más glam) que Kenneth Anger (siempre más trash). En sus momento, las acusaciones contra la vanguardia argentina insistían en la frivolidad, lo pretencioso, "el distraccionismo mini-burgués”. Cuando Rocha y los directores del cinema novo embisten contra el cinema marginal, en cambio, lo acusan de "anarcodireitista", "fascista", "dileitante" o "colonizado". 15

Quizás el problema con estas películas es que, muy a menudo -dentro del clima fuertemente propositivo de ese momento histórico-, fueron criticadas por su contenido manifiesto, cuando lo cierto es que su verdadera denuncia política consistió en una intransigente resistencia a alinearse con cualquier propuesta. Sus directores no enuncian la violencia sino que son atravesados por ella. No proclaman el terror sino que se dejan poseer por él para hacerlo más evidente. Si es un cine destructivo, eso es porque -como un ave agorera- alerta sobre la destrucción Si eso es así, entonces estas películas subterráneas constituyen la profecía más precisa de un tipo de violencia estatal inédita que se estaba gestando y que, poco después, saldría a la superficie para dejar sus marcas terribles sobre Latinoamérica.

15 Para una crítica al “disconformismo estéril” del underground porteño contemporánea al movimiento, véase Miguel Grinberg, "Las olas bajan turbias”. 


\section{Bibliografía}

Avellar, José Carlos. O cinema dilacerado. Rio da Janiero: Alhambra, 1986.

Bazin, André, “De la dificulté d'etre Coco". Cahiers du cinéma no 91 (1959): 5259.

—. "Un festival de la culture cinématographique". Cahiers du cinéma no 34 (1954): 23-30.

Bernardet, Jean-Claude. “Cinema marginal?” Portal brasileiro de cinema. Web. 19 de abril de 2019.

Bernini, Emilio. "La vía política del cine argentino. Los documentales". Kilómetro $111 \mathrm{n}^{\mathrm{o}} 2$ (2001): 41-60.

Brakhage, Stan. "In Defense of amateur". Essential Brakhage: Selected Writings on Film-Making, Documentext, 2001. 142-150.

Bressane, Júlio. "La patología engendra el estilo" (entrevista de Eduardo Antín, et al). Estremecimientos. Júlio Bressane y el cine. Buenos Aires: BAFICI, 2013. 29-58.

—, et al. "O eu da arte é fora de si”. Cinemais no 33 (2003): 9-53.

Cabral, Sérgio et al. "Helena -a mulher de todos- e seu homem (entrevista com Rogério Sganzerla e Helena Ignez)”. O Pasquim no 33 (1970) Web.19 de abril de 2019.

Caughie, John (ed.). Theories of Authorship: A Reader. London And New York: Routledge, 1990.

De Baecque, Antoine (ed.) La politica de los autores. Manifiestos de una generación de cinéfilos. Barcelona: Paidós, 2003.

Dreyer, Sylvain. "Le cinéma militant et le mythe du collectif". La création collective au cinéma $\mathrm{n}^{\circ} 1$ (2017): 29-45.

Faroult, David. "Never more Godard. Le Groupe Dziga Vertov, l'auteur et la signature". Jean-Luc Godard. Documents, editado por Nicole Brenez et al., Paris: Éditions du Centre Pompidou, 2006. 120-135. 
Ferreira, Jairo. Cinema de invenção [1986]. Sao Paulo: Azougue, 2016.

Getino, Octavio y Susana Velleggia. El cine de las historias de la revolución. Buenos Aires: Altamira, 2000.

Godard, Jean-Luc y Fernando Solanas. "Godard por Solanas, Solanas por Godard". Cine del Tercer Mundo n 1 (1969): 48-63.

Grinberg, Miguel. "New American Cinema. 3 al 17 de agosto de 1965". La generación " $V$ ": La insurrección contracultural de los años 60. Buenos Aires: Emecé, 2004. 141-148.

__. "Las olas bajan turbias. El Viejo 'Nuevo Cine' argentino". Cine \& Medios no 2 (1969): 34-40.

Hennebelle, Guy. Cinéma et politique. De la politique des auteurs au cinéma d'intervention. Paris: Papyrus-Maison de la culture de Rennes, 1980.

Machado, Rubens. "Pasos e descompasos à margem". Alceu, vol. 8, núm. 15, (2007):164-172.

Mestman, Mariano. "Aproximaciones a una experiencia de cine militante (Argentina, 1968-1973)". VV.AA., Arte y poder: V Jornadas de Teoría e Historia de las Artes. CAIA (1993): 68-83.

Rocha, Glauber. Cartas ao mundo. San Pablo: Companhia das letras, 1997.

—. "Udigrudi: uma velha novidade". Arte em revista $\mathrm{n}^{\circ} 5$ (1981): 80-82.

Rodowick, David. The Crisis of Political Modernism.Berkeley University of California Press, 1994.

Sarlo, Beatriz. La máquina cultural. Maestras, traductores y vanguardistas. Buenos Aires: Ariel, 1998.

Sganzerla, Rogério. “A mulher de todos para seu autor" [1970]. Contracampo ${ }^{\circ}$ 38.Web. 19 de abril de 2019.

_. "Necrológio de um gênio" [1981]. Sibila. Revista de poesía e crítica literaria, 2010.Web. 19 de abril de 2019.

. "A questão da cultura" [1970]. Contracampo. Revista de cinema n ${ }^{\circ} 61$. Web. 19 de abril de 2019. 
—_. "Cinema fora da Lei" [1968]. O bandido da luz vermelha. Argumento e roteiro. Sao Paulo: Imprensa oficial do Estado de São Paulo (2008): 1517.

Silva, Mateus Araújo. "Godard, Glauber e o Vento do leste: alegoria de um (des)encontro". Devires vol. 4, n 1 (2007).

Solanas, Fernando y Octavio Getino. Cine, cultura y descolonización. Buenos Aires: Siglo XXI, 1973.

Stam, Robert. "Brazilian Avant-Garde Cinema: from Limite to Red Light Bandit". Millennium Film Journal no 4-5 (1979): 32-42.

Vieira Caetano, Daniel Pecego. Entre a transgressão vanguardista e a subversão da vulgaridade: Os casos de Carlos Reichenbach e Alberto Fischerman. Tesis de doctorado, Pontifícia Universidade Católica do Rio de Janeiro, 2012.Web. 19 de abril de 2019.

Vieira, João Luiz. "Chanchada e a Estética do lixo". Contracampo. Revista do Mestrado em Comunicação, Imagem e Informação nº 13 (2000):169182.

Wolkowicz, Paula. "El héroe ausente. La figura del líder, del pueblo y del intelectual en el cine marginal brasileño y en el cine underground argentino". Cine y revolución en América Latina: una perspectiva comparada de las cinematografias de la región. Ana Laura Lusnich et al.(Ed). Buenos Aires: Imago Mundi, 2014. 161-176.

Xavier, Ismail. Alegorias do subdesenvolvimento. Cinema novo, tropicalismo e cinema marginal. Sao Paulo: Cosac Naify, 2014.

—. "Bazin in Brasil: A Welcome Visitor". Opening Bazin. Postwar Film Theory and Its Afterlife. Dudley Andrew (Ed). New York: Oxford, 2011. 308-315.

__. "Roteiro de Júlio Bressane: apresentação de uma poética". Alceu, vol. 6, núm. 12 (2006): 5-26. 
. "O cinema marginal revisitado, ou o avesso dos anos 90". Cinema marginal brasileiro e suas fronteiras, editado por Eugênio Puppo y Vera Haddad, Centro Cultural Banco do Brasil (2001): 21-23. 